\title{
GREM1 Gene
}

National Cancer Institute

\section{Source}

National Cancer Institute. GREM1 Gene. NCI Thesaurus. Code C151999.

This gene is involved in the downregulation of bone morphogenetic protein signaling. 